Agro-Science Journal of Tropical Agriculture, Food, Environment and Extension Volume 11 Number 3 September 2012 pp 51 - 56 TSSN IIIY-7455

\title{
ECONOMICS OF UPLAND RICE (ORIZA SATIVA) PRODUCTION IN IVO LOCAL GOVERNMENT AREA OF EBONYI STATE, NIGERIA
}

\author{
Ume $^{1}$, S.I., Jiwuba ${ }^{2}$, F.I., and Ochiaka ${ }^{3}$, C.D. \\ ${ }^{1}$ Federal College of Agriculture, Ishiagu, Ebonyi State \\ ${ }^{2}$ National Horticultural Research Institute (Nihort), Mbato Station Okigwe \\ ${ }^{3}$ Department of Agricultural Economics and Extension, Enugu State University of Science \\ and Technology. Enugu \\ Corresponding author E-mail : umesmilesi@gmail.com
}

\begin{abstract}
Economic analysis of upland rice production in Ivo Local Government Area of Ebonyi State was done. Data were generated through structured questionnaire and oral interview schedules administered on one hundred and twenty rice farmers, which were selected randomly from the local government area. The data were analysed using Cobb Douglas production function, budgetary system and descriptive statistics. The results showed that Cobb Douglas production function was the lead equation because of highest $R^{2}=(0.7725)$ and highest number of significant variables. Thus $77.3 \%$ of the variation in rice output is explained by the variables included in the model. The elasticity of rice production showed that all inputs were inelastic since they all have marginal value products less than 1. The return to scale was greater than lindicating an increasing return to scale. Resource use efficiency showed that the farmers did not achieve optimum allocative efficiency in the use of any of the farm resources. Net farm analysis showed that the total cost of production of rice was $\mathbf{1 6 9 , 2 8 0}$ per hectare with total revenue of $\$ 140,460$. The net farm income was $\$ 71,180$, which implies that rice production is profitable in the study area. Most farmers complained of poor access to credit and high cost of labour as major obstacles to rice production. Policies that will enable farmers to employ more of their production resources such as encouraging the retribution and reallocation of resources should be made possible in order to improve farmers, performances. Also, increasing farmers' access to production inpus; (fertilizer, improved varieties and land) were advocated.
\end{abstract}

Keyword: Economics, Allocative, efficiency, rice, production

\section{INTRODUCTION}

Rice is among the emerging staple and commercial crops grown in many developing countries (Hyuba, 2007). Rice consumption in Nigeria has attained position of pre-eminence which is evident in the average Nigerian consumption of $21 \mathrm{~kg}$ of rice per year representing $9 \%$ of total caloric intake and $23 \%$ of total cereal consumption (Onwuka et al, 2010). The growing rate of per caput consumption of rice could be related to increased per capita income, rapid population growth, change in the diet, taste and diets of average Nigerians (Onyenweaku et al, 2010) as well as to the ease with which rice can be preserved and prepared for the table (Nwagbo and Onwuchekwa, 1999). In effect, rice consumption in the country outstrips the domestic production, resulting in enormous imports both in quantity and value at various times to checkmate the production gap (Daramola, 2005). FAO. (2004) reported that rice production in Nigeria between
2001 and 2003 was 2.03 million megagrams, while consumption was 3.96 million megagrams. WARDA (2005) reported that Nigeria imported 1.7 million tons of rice in 2001 and 1.5 million tons in 2003 to balance her production deficit.

One of the ecologies of rice is upland, with an area of 14 million hectares and accounting for $11 \%$ of the world rice area (Oyewole et al, 2010). In Nigeria, out of 4.6 4.9 million hectares used for rice production (Nwilene, 2009), 25\% is devoted to upland rice (Onyishi et al, 2010). Generally, rice is grown sole in most rice producing areas of Nigeria. However, some rice farmers do cultivate other crops on their rice fields. Such crops are usually grown either after rice or along with rice but only in those parts of the field which are less suitable for rice cultivation (Adeniyi, 1999).

The Nigeria's upland rice cropping system is beset with problems low yield, relatively high production costs, relatively low 
producers' prices and poor marketing system. These have led to low returns and hence to the decline in domestic rice production (FAO, 2004). In spite of the above research emphasis has been on agronomy of rice production in Nigeria. There is paucity of information as regards economic analysis of rice production, particularly in the Ebonyi State of Nigeria. This study deals with the production function for efficiency, elasticity of production and return to scale, resource use efficiency, problems associated with rice production and the profitability of rice production in Ivo Local Government. Area of Ebonyi State Nigeria.

\section{MATERIALS AND METHOD}

The study was conducted in Ivo Local Government Area (LGA) of Ebonyi State. Ivo L.G.A. is located at latitude $5^{0} 56^{\prime}$ and $6^{0} 59^{\prime} \mathrm{N}$ of Greenwich Meridian and $7^{0} 31^{\prime}$ and $7^{0} 41^{\prime} \mathrm{E}$ The annual rainfall ranges from 1500 to $2500 \mathrm{~mm}$, temperature ranging from $28^{\circ}$ to $45^{\circ} \mathrm{C}$ and relative humidity of $65 \%$. Ivo L.G.A comprises four autonomous communities namely: Ishiagu, Ihe, Umuihe and Akaeze with Isiaka as administrative headquarter. Ivo L.G.A. is bounded in the North by Ohaozara, Aninri and Awgu L.G.As, in the east by Onicha L.G.A and in the west by Umunneochi and Isuikwato L.G.A of Abia State. The local government area covers an average of $3,506 \mathrm{sqkm}^{2}$ with population figure of 220.919 people (NPC, 2006). The people of Ivo L.G.A. are predominantly agrarians who grow crops such as rice, cassava, yam and vegetables. The major animals reared include goats, sheep and poultry.

Multi-stage random sampling technique was used to select towns, villages, and respondents. In the first stage, three towns were selected out of four. The selected towns were Ishiagu, Umuihie and Akaeze. In the second stage, four villages were randomly selected from each of the towns. This brought a total of twelve villages. Finally, from the list of rice farmers provided by the extension agents and local leaders, 10 rice farmers each were selected randomly from these villages for the study. This gave a total of 120 farmers for detailed study. Structured questionnaire and oral interview were used to collect information on input and output prices and limiting factors to rice production.

Data were analysed using ordinary least square estimation technique, marginal ratio analysis, descriptive statistics and farm budgeting technique. Four functional forms (linear, semi-log, exponential and CobbDouglas) of production function were tried and explicitly represented as:

Linear function:

$\mathrm{Y}=\mathrm{b}_{0}+\mathrm{b}_{1} \mathrm{x}_{1}+\mathrm{b}_{2} \mathrm{x}_{2}+\mathrm{b}_{3} \mathrm{x}_{3}+\mathrm{b}_{4} \mathrm{x}_{4}+\mathrm{b}_{5} \mathrm{x}_{5}+\mathrm{e}--(1)$
Double $\log$ function (Cobb Douglas):

$\operatorname{In}(\mathrm{y})=\operatorname{Inb}_{0}+\mathrm{b}_{1} \operatorname{In} \mathrm{x}_{1}+\mathrm{b}_{2} \operatorname{Inx}_{2}+\mathrm{b}_{3} \operatorname{In} \mathrm{x}_{3}+\mathrm{b}_{4} \operatorname{Inx}_{4}+$

$\mathrm{b}_{5} \operatorname{Inx}_{5}+\mathrm{ei}$

Semi double log function:

$\mathrm{Y}=\operatorname{Inb}_{0}+\mathrm{b}_{1} \operatorname{Inx}_{1}+\mathrm{b}_{2} \operatorname{Inx}_{2}+\mathrm{b}_{3} \operatorname{Inx}_{3}+\mathrm{b}_{4} \operatorname{Inx}_{4}+$ $\mathrm{b}_{5} \operatorname{Inx}_{5}+\mathrm{ei}$

\section{Exponential function:}

In $Y=b_{0}+b_{1} x_{1}+b_{2} x_{2}+b_{3} x_{3}+b_{4} x_{4}+b_{5} x_{5}+$ ei- (4) $\mathrm{Y}=$ rice yield $(\mathrm{kg}), \mathrm{X}_{1}=$ farm size $(\mathrm{ha}), \mathrm{X}_{2}=$ seed $(\mathrm{kg}), \mathrm{X}_{3}=$ fertilizer $(\mathrm{kg})$,

$\mathrm{X}_{4}=$ labour (manday), $\mu=$ error term, $\mathrm{A}_{0}=$ constant, $\beta_{1}-\beta_{4}=$ coefficient estimates with respect to the input used.

The choice of the best functional form was based on the magnitude of the $\mathrm{R}^{2}$ value, the number of variables significant, size and signs of the regression coefficients as they conform to apriori expectation.

The marginal inputs used by rice farmers in the study area were computed to estimate the allocative efficiency of the resources and the required adjustment in marginal value product for optimal allocation of the variable inputs was computed. The model is stated as.

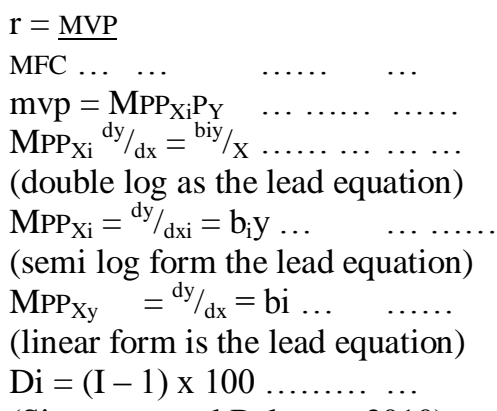

$\mathrm{Di}=(\mathrm{I}-1) \times 100 \ldots \ldots \ldots$
(Simonyan and Balogun, 2010)

$\mathrm{r}=$ efficiency ratio notation; $\mathrm{MVP}=$ marginal value product; $\mathrm{MFC}=$ marginal factor $\operatorname{cost}(\operatorname{cost}$ of unit price of a particular input); MPP = marginal physical product $=$ arithmetic means of the yield and input; considered respectively; Py $=$ the unit price of output; $\mathrm{Xi}=$ various input to $\mathrm{n} ; \mathrm{r}_{1}=$ ratio of MVP to MFC for the $\mathrm{i}^{\text {th }}$ resource; If; $r=1, \mu$ implies that resources are efficiently utilized i.e. $\mathrm{MVP}=\mathrm{MFC}=1 ; \mathrm{r}>1$; implies that resources are under utilized; $\mathrm{r}<1$; implies that resources are over utilized

\section{Elasticity of production and return to scale}

The elasticity of production is the measure of percentage change in output due to percentage change in the individual resource used in rice production. The return scale (sum of elasticity) which is the response of output to proportionate change in input were estimated (Gujarati, 2004). Where the sum is I = constant return to scale. If the sum is less than $\mathrm{I}=$ decreasing returns to scale. If the sum is greater than $\mathrm{I}=$ increasing return to scale. The regression coefficients in 
the Cobb Douglas are the elasticities and their sums indicate the returns to scale.

The model is stated:

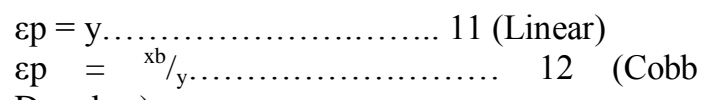

Douglas )

$\varepsilon \mathrm{p}=\mathrm{xb} / 2$ $13($ Semi log)

where:

$\varepsilon \mathrm{p}=$ elasticity of production; $\quad \mathrm{y}=$ output quantity; $\mathrm{x}=$ input quantity $; \mathrm{b}_{2}=$ regression coefficient of input variable; RTS $=$ return to scale

\section{RESULTS AND DISCUSSION}

Table I shows the estimated Cobb Douglas production function for rice. Cobb Douglas production function was selected as shown in Table 1 based on high number of significant variables of five and high value of coefficient of determination $\left(R^{2}\right)$. It has $R^{2}$ value of 0.7725 , implying that the independent variable included in the model accounted for $77 \%$ of the variation in rice output, while the remaining $23 \%$ was due to error. All the variables considered; seed $\left(\mathrm{x}_{1}\right)$, fertilizer $\left(\mathrm{x}_{2}\right)$, farm size $\left(\mathrm{x}_{3}\right)$ and labour $\left(\mathrm{x}_{4}\right)$ were positively signed and conformed to apriori expectation. The coefficient of farm size and fertilizer were significant at $1 \%$ level of probability. This finding is consistent with Okoye and Onyenweaku (2008) whose results showed positive relationship between farm size and output. This implies that the increase in farm size will consequently result to increase in output of rice with other variables constant. Farm size, according to Abara and Singh (1993), affects adoption cost, risk perception, human capital, credit constraints, labour requirement and tenure arrangement which affect the farmers' output.

The coefficient of fertilizer was significant at $1 \%$ level of probability. Several studies (FAO, 2004; Awuwa, 2008, Eze and Akpa, 2010) posited that fertilizer is an important determinant of agricultural productivity, and has the capacity to shift production frontier upwards. Onyenweaku et al, (2010) found negative relationship between fertilizer and output of rice. This could be as a result of high cost of the production resource, hence constraining poor resource farmers' use. The coefficient of seed was significant at $5 \%$ level of probability. The implication is that the quantity of output produced is a function of the quantity of seed used in the production circle. Simonyan and Balogun (2010) and Nwakor et al (2010) reported simlar relationship unlike Nwagbo and Onwuenekwa (1999) who reported limited use of improved varieties by farmers when compared to local varieties because of the high cost of the former. This results in low yield. The coefficient of labour was significant at $10 \%$. Labour is an important determinant of the quantity of output produced. Nevertheless, because of high cost of hired labour, most rural households resort to the use of children labour which is often inefficient resulting to low output (Enaghase, 2006).

Table I: Estimated Multi-stage Regression Production Function for Upland Rice Farmers

\begin{tabular}{|c|c|c|c|c|}
\hline Variable & Linear & Semi log & Exponential & Cobb Douglas \\
\hline \multirow[t]{2}{*}{ Constant } & 3.328 & 4.414 & 6.721 & 9.772 \\
\hline & $(4.728)^{* * * *}$ & $(3.701)^{* * *}$ & $(4.313)^{* * *}$ & $(5.006)^{* * *}$ \\
\hline \multirow{2}{*}{ Farm size $\left(\mathrm{x}_{1}\right)$} & 0.612 & 2.312 & 0.317 & 0.072 \\
\hline & $(0.121)$ & $(3.110)^{* *}$ & $(1.720)^{*}$ & $(3.14)^{* * * *}$ \\
\hline \multirow[t]{2}{*}{ Seed $\left(x_{2}\right)$} & 1.001 & 0.345 & 2.774 & 0.649 \\
\hline & $(0.728)$ & $(1.701)^{*}$ & $(0.331)$ & $(2.004)^{* *}$ \\
\hline \multirow[t]{2}{*}{ Fertilizer $\left(\mathrm{x}_{3}\right)$} & 2.317 & 3.007 & 0.041 & 0.974 \\
\hline & $(2.007)^{* *}$ & $(0.007)$ & $(2.031)^{* *}$ & $(2.64)^{* * *}$ \\
\hline \multirow[t]{2}{*}{ Labour $\left(\mathrm{x}_{4}\right)$} & 0.552 & 1.004 & 0.492 & 0.584 \\
\hline & $(3.081)^{* * *}$ & $(0.699)$ & $(0.916)$ & $(2.08) * *$ \\
\hline $\mathrm{R}^{2}$ & 0.558 & 0.6572 & 0.6104 & 0.7725 \\
\hline F-value & 58.27 & 62.44 & 75.27 & 89.23 \\
\hline
\end{tabular}

Source: Field Survey, 2010

Table 2: Elasticity of Production and Return to Scale of Rice

\begin{tabular}{lc}
\hline Variable & Elasticity of production \\
\hline Farm size & 0.051 \\
Seed & 0.472 \\
Fertilizer & 0.282 \\
Labour & 1.68 \\
Return to scale & 2.485 \\
\hline Source Field Surver, 2010 &
\end{tabular}

Source: Field Survey, 2010 
Table 2 shows elasticity of production and return to scale of upland rice farmers in the study area. The regression coefficients in the Cobb Douglas production function are the elasticities and their sums indicate the return to scale (Hazarika and Subramanian, 1999). The elasticity of production shows the change in output relative to a unit change of input (Mbanasor and Obioha, 2003). Table 2 also indicates that farm size, seed and labour had production elasticities less than one. This implies that these resources and rice output had inelastic relationship, thus when the inputs utilization is increased by $1 \%$ less than $1 \%$ increase in the rice output will result. Fertilizer had production elasticity greater than one, which indicates elastic relationship between the resource and rice output. The return to scale of the inputs used in rice production was greater than one. This means that rice farmers' production plan is elastic and operate in stage II of production function (rational stage of production), which implies that farmers optimally utilize and allocate their production inputs, particularly fertilizer. This finding is in consonance with the assertion of Eze and Akpa (2010), who associated farmers in stage two of production function as having high and positive coefficient of fertilizer and low and positive coefficient of depreciation.

Table 3 shows the resource use efficiency of upland rice farmers. Cobb Douglas estimates were used to compute the marginal productivities of the inputs measured in monetary term. The efficiency of rice farmers is computed by comparing the ratio of the marginal value product of each input to their respective purchasing cost. As indicated in Table 3, the efficiency ratio of fertilizer and farm size were 13.349 and 4.769 respectively, implying that the inputs were under utilized. The high cost and unavailability of fertilizer at farm level at right time could be reasons why poorer rice farmers do not use fertilizer optimally in their farms. The under utilization of farm size is in conformity to Iheke (2006) who posited that farms in most developing countries are usually small sized, fragmented and not contiguous land holding. Moreso, according to Ume et a.l (2009), the traditional land constraints to female farmers impair their production expansion bid. To optimize the profit of rice in the study area fertilizer and farm size should be increased by $12.3 \%$ and $-3.84 \%$ respectively from their present level.

Table 3: Resource efficiency of rice farmer

\begin{tabular}{lllll}
\hline Variable & MVP & MFC & AE $_{1}$ & Resource utilization and required change \\
\hline Farm size & $56,510.2$ & 11849 & 4.769 & Under utilized - 3.846 \\
Seed & 49.42 & 1250 & 0.040 & Over utilization 96.0 \\
Fertilizer & 334.90 & 100 & 13.349 & Under utilized 12.337 \\
Labour & 49.55 & 61 & 0.812 & Over utilized 20.32 \\
\hline Source Fied & & & &
\end{tabular}

Source: Field Survey, 2010

Table 4: Cost and returns analysis in rice production

\begin{tabular}{lcc}
\hline \multicolumn{1}{c}{ Item } & Cost and returns ( $\mathbf{(})$ & \% cost \\
\hline Variable cost & & 3.0 \\
Transportation & 2000 & 1.9 \\
Storage & 1,280 & 53.9 \\
Hired labour & 35,500 & 34.6 \\
Fertilizer & 22,800 & 6.4 \\
Seed & 4,200 & \\
Total variable cost & 65,880 & 4.9 \\
Fixed cost & & 100 \\
Implement (hoe and cutlass) & 3,400 & \\
Total fixed cost (TFC + TVC) & 69,280 & \\
Rice returns (\#) & 140,460 & \\
Net farm income & 71,180 & \\
Return per Naira & 1.03 & \\
BCR & 2.03 & \\
\hline Source: Field Surver & &
\end{tabular}

Source: Field Survey, 2010 
Table 5: Constraints of rice production in the study area

\begin{tabular}{lc}
\hline \multicolumn{1}{c}{ Constraints } & Percentage \\
\hline Poor access to credit & 78 \\
High cost of labour & 68.4 \\
High cost of transportation & 56.4 \\
Inadequate extension services & 60.2 \\
Problems of Fulani cattle rearers & 36.4 \\
High cost of fertilizer & 58.4 \\
\hline Multiple response & \\
Source: Field Survey, 2010 &
\end{tabular}

The efficiency ratio of seed and labour were 0.040 and 0.812 respectively. These imply over-utilization of the resources. The abuse of family and children labour which accounted insignificantly to the total cost of production would explain the behaviour of the variable (Onyenweaku et al, 2010). To optimize the profit of upland rice in the study area fertilizer and farm size should be increased by $12.5 \%$ and $-3.84 \%$ respectively from their current level. Also, seed and labour should be reduced from their current level of use by $96 \%$ and $20.3 \%$ respectively.

Table 4 shows the cost and returns of rice farmers using 2010 market prices of inputs and output. The analysis revealed that labour constituted the highest (53.9\%) of the total cost of production. Ezedinma reported that with the increase in population, rural urban migration, ageing of the rural population and feminization of agriculture, the labour cost is likely to be inelastic and expensive. This finding conforms with Ume et al, (2009) but disagrees with Simonyan and Balogun (2010) on economics of sesame production. The least cost of the total cost of production was cost of seed (6.4\%). The average total cost of production was $\$ 69,280$ per hectare, while the revenue from rice production was $\$ 140,460$ per hectare. The net farm income was $\$ 71,180$, which implies that rice production is profitable in the study area. Moreso, the benefit cost ratio of rice farmer was 2.03 , implying that for every one Naira spent, about $\$ 2.03$ was obtained in return. Table 5 shows the constraints to rice production. The study revealed that $78 \%$ of the farmers interviewed encountered poor access to credit as constraint to rice production.

Poor access to credit would imply lack of access to production inputs that will enhance adoption of improved farm practices as well as expand their operations (Ume, et al, 2009). Poor access to credit by farmers through the lending agencies could be because of problems of collaterals, high interest rate, short term loan repayment and red-tapism involved in obtaining credit especially from formal organizations (Omuriyi et al, 1999). About $68.4 \%$ of the respondents experience the problem of high labour cost. Ezedinma, (2006) advocated that farmers form communal labour to ease the problem of high cost of labour.

\section{CONCLUSION AND RECOMMENDATION}

Rice is a profitable venture despite the constraints in the study area. The profit margin can be enhanced through policies designed to improve farmers' access to productive inputs at subsidized prices and encourage the reallocation and redistribution of farm inputs.

\section{REFERENCES}

Abara, I.O. and Singh, S. (1993): Ethics and biases in technology adoption. The small farm argument technological forecasting and social change: 43: 289 -300 .

Adeniyi, J.P. (1999): On farm research results on Nigeria's rice cropping systems: A Review. Proceedings of the National Farming Research Network workshop held in Jos, Plateau State, Nigeria; May $10-13$, pp. 341.

Awuwa, C. (2008): Adoption and profitability of rice production among farmers in Ikwuano L.G.A. of Abia State, Nigera. Unpublished Higher National Diploma (HND) of Federal College of Agriculture Ishiagu, Ivo L.G.A. Ebonyi State.

Daramola, B. (2005): Adoption of rice production technology in Nigeria: A case study of Oyo State farmers. Proceedings of National Farming System Research Network workshop held in Jos, Plateau State.

Enaghase, S. (2006): "Child labour on the increase in Africa": Labour and Employment. Daily Independent, June 8 2006. $17 \mathrm{p}$.

Eze, C.I. and Akpa, C.E. (2010): Analysis of technical and national FADAMA II facility on arable crop farmers in Imo State, Nigeria. The Nigerian Agricultural Journals 41(2): 109 - 115.

FAO (2004): Statistical database, FAOSTAT 2003, Food and Agriculture Organization, Rome. 
Hazarika, C. and Subramanian, S.R. (1999): "Estimation of technical efficiency in the stochastic frontier production function model: An application to the tea industries in Assarn." Journal of Agricultural Economics, 54(2): 201211.

Hyuba, T.S. (2007): Analysis of profit inefficiency in rice production in Eastern and Northern Uganda. African Crop Science Journal 15(4): 243 - 253.

Iheke, R.O. (2006): Market access income diversification and welfare status of rural farm households in Abia State, Nigeria. Nigeria Agricultural Journal 42(2): $13-17$.

Mbanasor, J.A. and Obioha, I.O. (2003): Resource productivity under FADAMAs cropping system in Umuahia North local government area of Abia State. Journal of Tropical and Sub-Tropical Agro ecosystems 2: 81 $-86$.

Nwagbo, E.C. and Onwuchekwa, S.C. (1999): Economics of rice production by farmers in Abakaliki area of Anambra State. Proceeding of the National Farming System Research Network workshop held in Jos, Plateau State, Nigera. Pp. 172 - 179.

Nwakor, F.N; Ifenkwe, G. and Ekwe, K.C. (2010): Determinants of Adoption of improved cassava varieties (TME 419 and NR 8082) among farmers in Abia State. Nigeria Agricultural Journal 41(1): $94-98$.

West African Rice Development Agency (WARDA) (2005): Strategic plan 2003 - 2012, Buroake, Cote d'ivore.
Nwilene, F.E; Ajayi, O. and Semon, M (2009): WAROA's contribution to FADAMA III Project. FADAMA III workshop, IITA, Ibadan.

Omuriyi, S.A; Orhue, U.X; Akeroba, A.A. and Aghimiem, C.I. (1999): Prescribed agricultural science for senior secondary schools. Revised edition, Idodo Ume Publishers Ltd.

Onwuka, S; Ekwe, K.C. and Ekwe, C.C. (2010): Comparative analysis of foreign and local rice demand in Ikwuano and Umuahia North local government areas of Abia State, Nigeria. The Nigerian Agricultural Journal 41(1): 157 - 161.

Onyenweaku, C.E; Okoye, B.C. and Okorie, K.C. (2010): Determinants of fertilizer adoption by rice farmers in Bende Local Government Area. The Nigeria Agricultural Journal 41(1): 1 - 6 .

Onyishi, G.C; Ajagu, C.O; Onuoha, E.R. and Dialoke, S.A. (2010): Evaluation of the performance of upland rice cultivars as affected by fertilizer levels in a clay loam uttisol. The Nigerian Agricultural Journal, 41(1): $72-77$.

Simonyan, J.B. and Balogun, O.S. (2010): Economic analysis of sesame (Sesamum indiam L) productin in Okene local government area of Kogi State. The Nigerian Agricultural Journal, 41(1): $19-24$.

Ume, S.I; Okoronkwo, M.O. and Uloh, V.E. (2009): Adoption of improved rice production technology by farmers in Anambra State. Ebonyi Technology and Vocation Journal, 6(1): 1 - 3 . 